\title{
Nationalism and Democracy Revisited
}

The Limits of Democratic Nationalism in South Korea*

Jun-Hyeok Kwak

(Soongsil University)

$\langle$ CONTENTS〉

I . Introduction

II . Theoretical Overview

III. Origins of Democratic Nationalism

1. Two Elements of Statist Nationalism in South Korea

2. Two Traits of Democratic Nationalism

IV. Weak Civil Society with Democratic Nationalism

- Key words : South Korea, nationalism, democratic nationalism, statist nationalism, non-domination

[ABSTRACT 】

In this article I explore the limits of democratic nationalism, whose political claims to civic unity cannot consolidate democratization at the local level. First, explaining why antiauthoritarian nationalism in South Korea failed to overcome the statist aspiration for democratization during the transition to democracy in 1987, I argue that the benefits of strong nationalistic inclination in South Korea are less tightly connected

\footnotetext{
*This work was supported by the National Research Foundation for Korea Grant funded by the Korean Government (N RF-2010-330-B00151).
} 
to the values of grassroots democracy. Second, I emphasize that while nationalism or national unity is not necessarily incompatible with democracy, it should be supplemented with the values of nondomination as intermediate ideals conducive to regulate a civil society in tension.

\section{I . Introduction}

Nationalism in South Korea (hereafter Korea) is more than what meets the eye. It has additional implications beyond the instruments of political ideology that consolidates social cohesion, and mobilizes the people in action. As an ultimate value transcending the left-right ideological division and as a crucial drive to establish a common identity for Korean society, nationalism resides deeply in the Korean psyche. Obviously, intellectual movements have pointed out the fictitiousness of nationalism, and tried to dismantle the seemingly irrevocable frame of nation-centered discourse. Nevertheless, the scheme of memory and oblivion offered by Korean nationalism has not been divested but rather reinforced in the globalized life of Koreans. The background of nationalism is deeply rooted in Korean individuals as a cultural and ethical milieu, which realizes the experiences of the past and expectations for the future.

However, a recent public survey conducted by SSK Civic Solidarity Research Group from 25 May-5 June 2012, shows an interesting feature of South Korean civil society. While South Koreans have such a strong national commonality, they are far less interested in their locality and its political imperative. ${ }^{1)}$ To questions regarding their actual participation in public affairs at the provincial and neighborhood level, half of all respondents $(53.5 \%)$

1) See Social Science Korea-Civic Solidarity Research Group, Social Survey on Civic Solidarity in South Korea (Seoul: Korea University, 2012), p. 1. This survey was conducted through CAWI (Computer-Assisted W eb Interviewing with electronic questionnaires), and its sample population, which consists of 1,000 individuals over the age of 19 nationwide, was drawn by the sample distributions (region, sex, and five-year age group) in the annual reports of the permanent resident registration population in South Korea. The margin of error was plus or minus $3.1 \%$ with a confidence level of $95 \%$. 
answered that they never take part in any meetings organized in their provinces and neighborhoods, while $17.9 \%$ attended, or took part in, at least once in provincial or neighborhood meeting. This result corresponds to the priority of all respondents over their senses of belonging to public or private associations. Among respondents who answered that they regularly attended social gatherings, only $5.2 \%$ answered that civic engagement in local associations was imperative for them. ${ }^{2}$

Interestingly enough, the indifference of Korean citizens toward local affairs does not appear to play a key role in explaining the character of civic life in Korean society, since most of respondents (over $80 \%$ ) feel a strong sense of civic duty at the national level. Actually, while their sense of obligation to local matters was as low as about $40 \%$, they positively responded to all questions regarding civic responsibility at the national level. For instance, $85.1 \%$ of those who never attended any local meetings took part in the general election held in April 2012. This indicates that most respondents still assume that civic duties, including paying taxes and participating in elections, are crucial for the successful development of their civic and private lives. In brief, the weak link between lower civic engagement at the local level and higher political participation at the national level leads us to investigate why these discrepancies in civic life have emerged and what role they play in shaping the characteristics of civil society in South Korea. In other words, the impact of Korean nationalism on civic life still flows through processes of national mobilization, which are not a function of consolidating democratization in daily life.

Based on these observations, by investigating the official and nonofficial narratives of antiauthoritarian nationalisms that spurred the democratization of South Korea in 1987, this article tackles a general presupposition that nationalism or nationality is a background condition of democratization and the consolidation of democracy. More specifically, it presents the following two arguments. First, I seek to explain why antiauthoritarian nationalism

2) I bid., p. 34, pp. 93-101, and p. 103. More than $65 \%$ were inclined to do with private associations relevant to their tastes and hobbies. By the same token, their preference over local associations including redevelopment issue was ranked at the lowest among nine categories. O nly $16 \%$ of all respondents answered that they had a chance to collaborate with their neighbors for collective actions regarding sociopolitical issues at the provincial and neighborhood level. 
failed to overcome the statist aspiration for democratization during the transition to democracy in 1987. I argue that the benefits of strong nationalistic inclination in South Korea are less tightly connected to the values of grassroots democracy or to the actualization of democratic deliberation than 'civic' nationalists suggest. Second, I emphasize that while nationalism or national unity is not necessarily incompatible with democracy, it should be supplemented not simply with the ideals of nationalism but with the values of democracy as intermediate ideals conducive to regulate a civil society between the extremes of nationalism and neoliberalism.

\section{II . Theoretical Overview}

Numerous scholarly publications highlight the dichotomy between liberaldemocratic nationalism and collective-totalitarian nationalism. On the basis of this dichotomy, Hans Kohn created two ideal types of nationalism, 'liberal, voluntary, civic Western' and 'illiberal, organic, ethnic Eastern' nationalism.' He presented the former as an example to show that nationalism could promote individual liberty. Although scholars have criticized Kohn's typology, it continues to remain highly influential in academic discourse. For instance, Liah Greenfeld portrays Britain and the United States as civic nations in which liberalism and nationalism are compatible with each other, while describing Russia and Germany as nations influenced by irrational resentment and ethnic commonality. ${ }^{4}$ Conceptualizing national identities in terms of liberal rights, Yael Tamir follows this line of argument, and tries to show that liberal nationalism is not an oxymoron. ${ }^{5)}$ In a similar vein, Will Kymlicka finds a way of reconciling multicultural commonality with liberal democracy. ${ }^{6}$

However, this dichotomy can hardly reflect historical reality if we take into

3) $\mathrm{H}$ ans Kohn, The Idea of $\mathrm{N}$ ationalism, A Study in Its Origins and Background ( $\mathrm{N}$ ew Brunswick, N J: T ransaction Publishers, 2005 [1944]).

4) Liah G reenfeld, N ationalism: Five Roads to M odernity (Cambridge, M A: H arvard U niversity Press, 1993).

5) Yael T amir, Liberal N ationalism (Princeton, N J: Princeton U niversity Press, 1995).

6) Will Kymlicka, M ulticultural Citizenship: A Liberal Theory of M inority Rights (N ew York: Oxford U niversity Press, 1996). 
consideration the political contexts of nationalist movements worldwide. Even if a national movement started with liberal-democratic nationalism from its inception, it could easily degenerate into collective-totalitarian nationalism at a later stage of its development. As the transitions from authoritarianism to democracy in Latin America and East Central Europe show, active participation in public affairs and democratic deliberation over political matters are frequently hampered by the nationalist-democratic aspiration for national unity. ${ }^{7)}$ In addition, although nationalism often goes hand in hand with democracy, antidemocratic nationalist demagogues, as the case of the former Yugoslavia shows, are occasionally able to foment wars. ${ }^{8}$ Certain forms of nationalism are not inimical to democratization; yet, we can hardly agree that liberal premises such as individualism and mutual respect are enough to steer nationalism to the proper direction.

Nevertheless, the association of nationalism with democracy has been firmly supported by a generally accepted assumption that 'nationality' as a sociopolitical solidarity is necessary for the functioning of democratic states. Some democratic theorists question this assumption by pointing out the normative and practical drawbacks of nationalistic affiliation as opposed to a democratic trust cultivated through the active participation of citizens in democratic process. ${ }^{9)}$ Still, the centrality of nationalism or nationality in instilling civic duty into citizens has been widely accepted by 'civic' nationalists. ${ }^{10)}$ David Miller, for example, defends nationalism in this sense.

7) Peri Pamir, "N ationalism, Ethnicity and D emocracy: Contemporary M anifestations," International Journal of Peace Studies 2-2 (1997); Peter Rutland, "D emocracy and N ationalism in Armenia," EuropeAsia Studies 46-5 (1994), pp. 839-861; M ate Szabo, "N ation-State, $\mathrm{N}$ ationalism and the Prospects for Democratization in East Central Europe," Communist and Post-Communist Studies 27-4 (1994), pp. 337-399.

8) Jack Snyder, From Voting to Violence: D emocratization and N ationalist Conflict (N ew York: W. W. N orton, 2000); Edward M ansfield and Jack Snyder, "D emocratization and War," Foreign Affairs 74-3 (1995), pp. 79-97.

9) Albert W. D zur, "N ationalism, Liberalism, and Democracy," Political Research Q uarterly 55-1 (2002), pp. 191-211; Jurgen $\mathrm{H}$ abermas, The Inclusion of the O ther: Studies in Political Theory, trans. by Ciaran Cronin (Cambridge, M A: M IT Press, 1996), pp. 105-153; James Bohman, Public D eliberation: Pluralism, Complexity, and D emocracy (Cambridge, M A: M IT Press, 1996); John D ryzek, Discursive Democracy: Politics, Policy, and Political Science (Cambridge, M A: Cambridge U niversity, 1990).

10) In this article, 'civic' nationalists refer to those theorists who seek to harness the motivational power of nationalism for democratic politics, while 'liberal' nationalists signify those theorists who seek to sublimate nationalism with culturally neutral political 
He maintains that national identity can provide citizens in a bounded territory not only with a normative source of individual dignity but also with a political rationale for civic duty. ${ }^{11)}$ Certain civic theorists justify the combination of nationalism and democracy in terms of popular sovereignty as the imperative ideal of democracy. For instance, emphasizing the historical context in which democracy came into being in the framework of popular sovereignty, Ghia Nodia claims that the idea of democracy never exists without nationalism. ${ }^{12)}$ In a similar vein, Pierre Manent justifies nationalism by highlighting how civic solidarity in modern democracy has been circumscribed by national boundaries and in what way our compassion for compatriots can be practically sustainable. ${ }^{13)}$

Furthermore, the relationship between nationalism and democracy has been justified in terms of national liberation. Certainly, most cases of state buildings in post-colonial societies were accompanied with a struggle for national liberation whose greater emphasis was chiefly drawn on the creation of a new nation-state or the realization of national independence. Therefore, the defense of nationalism in this sense covers a broad range of theories from transitology to post-colonialism. For example, Dankwart Rustow, whose transitology had a significant impact on authoritarian governments (including South Korea in the 1970s), suggested 'national unity' as the necessary precondition for realizing democracy in underdeveloped countries. ${ }^{14)}$

institutions. Certainly, 'civic' nationalism is different from 'liberal-democratic' nationalism at this juncture, although they are all critical of 'exclusive' and 'closed' nationalism. D ifferent from 'liberal' nationalists whose justification of nationalism is more or less based on a set of universal norms, civic nationalists maintain the view that we owe special obligations to our compatriots if our general duty to promote justice and our particular duty to a particular state conflict each other. Civic nationalists usually justify these special obligations to fellow members of one's nation by the narrowness of 'proximity' or 'compassion.' The principle of proximity has been supplemented with the presupposition that civic solidarity relies on civic responsibility which should be shared through democratic deliberation.

11) D avid M iller, Citizenship and National Identity (Malden, M A: Blackwell Publishers, 2000), pp. 81-96; On N ationality (N ew York: O xford U niversity Press, 1995), pp. 17-80.

12) G hia N odia, "N ational ism and D emocracy," J ournal of D emocracy 3-4 (1992), pp. 3-22.

13) Pierre $M$ anent, D emocracy without Nations? The Fate of Self-Government in Europe, trans. by Paul Seaton (W ilmington, DE: Intercollegiate Studies Institute, 2007).

14) D ankwart Rustow, "T ransitions to Democracy: T oward a D ynamic Model," in Lisa Anderson (ed.), Transitions to D emocracy (N ew York: Columbia University Press, 1999 [1969]), pp. 18-37. 
Although post-colonial theorists take their standpoints quite differently from how transitologists justify nationalism, their arguments appear to be similar when they presumed such a preponderant sense of loyalty toward a particular political community in previously or currently colonized nations. For instance, defining national liberation as a political movement for selfgovernment, Ranjoo S. Herr juxtaposes nonliberal nationalisms with the ideals of equal participation in democratic deliberation. At this juncture, she adumbrates the correlation between democracy and 'nonliberal' nationalism by identifying national membership as the self-identification of a culturally embedded agent as an equal participant in democratic deliberation. ${ }^{15)}$

The alliance of nationalism with democracy is particularly salient when a group of peoples aspire to create an autonomous state. Actually, a general trend since the Glorious Revolution in 1688 and the French Revolution of 1789 has been the genesis of nationality becomes the prevailing political assertion of a people organized to achieve popular sovereignty. ${ }^{16)}$ Civic nationalist claims to the need for national solidarity underscore one dimension of democracy, but underestimate the imperative of democratic practice that weaves a group of people to organize their institutions through political participation. As Craig Calhoun points out, ${ }^{17)}$ civic nationalists intentionally or unintentionally encourage us to ignore the rubric of 'civil society' which does not necessarily coincide with the existence of nationality or treat it as something identical with national solidarity. Particularly when we define civil society not simply as the web of relationships to which people within a state feel attached but as the set of social attitudes including trust and civility, we can hardly agree that nationality or nationalism is the only practically possible foundation for creating and maintaining social integration in democracy. By and large, the democratic capability of citizens depends on civil society through which they are provided with institutional and substantial capacities to enter into democratic deliberation. In other words, different from the claims of civic nationalists over nationality, the democratic

15) Ranjoo S. H err, "In D efense of N onliberal N ationalism," Political Theory 34-3 (2006), pp. 304-327.

16) Bernard Yack, "Popular Sovereignty and N ationalism," Political Theory 29-4 (2001), pp. 517-536.

17) Craig Calhoun, $\mathrm{N}$ ations $M$ atter: Culture, H istory, and the Cosmopolitan D ream ( $\mathrm{N}$ ew York: Routledge, 2007), pp. 51-101. 
potential of citizens within a state cannot be cultivated by the political assertion of national unity alone which is exogenous to democratic process itself.

The post-colonial defense of nationalism in terms of national liberation cannot solve the problem of civil society in the link between nationality and democracy. In the first place, we should note that the movements of national liberation are different from nationalism after the creation of the nation-state. Through world history, we have seen that the militant assertions of national liberation often ended up with antidemocratic demands for a higher degree of centralization and uniformization. In fact, it is quite evident that "nationalism in power is often a repressive ideology demanding strict adherence to the authority of the official embodiments of national tradition." ${ }^{18)}$ After the seizure of state power or the creation of nation-state, nationalism frequently imposes new strains upon society. For instance, the nationalist slogans of economic development in Latin America and Asia turned the original idea of development (that is, the realization of public freedom) into an abstract justification of heightened repressions. ${ }^{19)}$ In this context, we come to see that ensuring the loyalty of citizens through nationalism without considering the role of civil society in actualizing democracy ultimately habituates citizens to be subordinated to the ideological power of nationalism. Similarly, perpetuating the assertion that nationalism is the sole practical way for creating a civic solidarity, the defense of nationalism without taking account of civil society can leave aside the need for diversity through which citizens have the variety of alternative bases for social integration rather than nationality alone.

The Korean experience can help us to understand the imperative role of civil society in consolidating a democracy spurred by nationalism in its initial stage. Although South Korea is regarded as a successful case among late democratizers, its neoliberal idiosyncrasy which has been interwoven with strong nationalistic habituations turns out to be problematic. Despite the repetition of electoral competition for popular support since the democratization in 1987, the party system in South Korea has never been

18) Ibid., p. 97.

19) N igel H arris, National Liberation (Reno, N V : University of N evada Press, 1990), pp. 244268. 
stable in representing public opinions. Certainly, the weakness of party system does not necessarily correlate to the low quality of democracy. ${ }^{20)}$ However, the ineffective role of the party system in coalescing public opinions through democratic deliberation is problematic when it goes hand in hand with the recurrent crisis of political participation. ${ }^{21)}$ Furthermore, as noted earlier, the dissociation of citizens from locality encroaches the locus of civil society in South Korea without which the self-governing capacity of citizens can hardly be enhanced through democratic processes. Conversely, the ideological power of nationalism provoking national unity and national grandiosity remains intact in South Korea, and no regulative principle which can tame its ideological power seems to be workable even when it becomes the enemy of democracy. At this juncture, the political assertion of collective wisdom through democratic deliberation is not so much contributing to the consolidation of democracy in South Korea. By the same token, ephemeral uprisings responding to dramatic events cannot be transformed into institutional reforms.

\section{Origins of Democratic Nationalism}

The decisive question about the link between nationalism and democracy in South Korea is how it has thrived with the hollowness of civil society in South Korea. To answer this question, we need to investigate the interplay between structure and human practices, more specifically, the role of ethnocentric nationality in shaping the statist aspiration of nationaldemocratic discourse in South Korea. In this context, I analyze the nationaldemocratic discourses which contributed to the solidarity of dissident groups during the democratization of South Korea in 1987. With respect to the statist aspiration for national grandiosity, the antiauthoritarian or democratic nationalism shaped by the dissident groups in the 1980s was not so much different from the authoritarian or statist nationalism proposed by the authoritarian regime at the time.

20) $\mathrm{H}$ ans Stockton, "Political Parties, Party Systems and Democracy in East Asia: Lessons from Latin America," Comparative Political Studies 34-1 (2001), pp. 94-119.

21) Jang-Jip Choi, Democracy after Democratization: The Korean Experience (Stanford, CA: Asia-Pacific Research C enter, 2012). 


\section{Two Elements of Statist Nationalism in South Korea}

The origins of antiauthoritarian or democratic nationalism ${ }^{22)}$ during the democratization of South Korea in 1987 can be traced back to the emergence of anticommunism and developmentalism during the Syngman Rhee regime (1948-1960) and the Park Chung-hee regime (1963-1979). These two elements were shaped through interactions between collective experiences of the Korean people and state actions, and ultimately they became the crucial ingredients of statist nationalism in South Korea. ${ }^{23)}$ The former was concocted by the Rhee regime which sought to repress its political opponents after the failure of socioeconomic reform; the latter came out from moderate technocrats and intellectuals who wished to overcome severe poverty in 1960. Both of them were promulgated and indoctrinated by the authoritarian regimes, but they were sustained and reinforced through the collective experiences of the Korean people. Thus, at the very beginning, the proponents of antiauthoritarian or democratic nationalism were compelled to confront their ideological power.

The Korean War (1950-1953) was the event that made anticommunism predominant in the psyche of the Korean people. Before the war, ordinary

22) I argue that 'democratic nationalism' has two normative foundations: national selfdetermination and popular sovereignty. The former advocates national independence; the latter is the politics of nationality, aimed at redefining the legitimacy of sovereign power. They are virtually synonymous in terms of national security, but we can hardly underestimate the importance of popular sovereignty in facilitating the emergence of a more democratic government at the domestic level. This article concentrates on the latter category and its association with antiauthoritarian movements in South Korea, but without going so far as to claim that democratic nationalism in South Korea has been rigidly preoccupied with the issue of political participation. In this article, the ramifications of democratic nationalism in South Korea are translated into a nationalistic perspective that is aimed at promoting national self-determination and democratization.

23) H ere 'statism' or 'statist nationalism' does not refer to what theorists may call 'territorial' or 'civic' nationalism whose normative foundations are opposed to those of 'ethnic' or 'ethno-cultural' nationalism. In the $\mathrm{N}$ ortheast Asian countries, statism or statist nationalism has been shaped by Confucian cultural legacies and particular historical experiences. Confucian cultural traditions, in which state and society constitute a moral and ethical unity, still persist, and induce patriots to accept 'statism' as a way to secure harmony and stability in a country. Similarly, the historical experiences which gave rise to state nationalism in the $\mathrm{N}$ ortheast Asian countries keep reasserting the need for a strong state. $\mathrm{On}$ the definition of 'statist nationalism' and its problems, see Chaim Gans, The Limits of $\mathrm{N}$ ationalism ( $\mathrm{N}$ ew York: Cambridge U niversity Press, 2003), pp. 7-38. 
citizens often lacked a clear-cut ideological preference either for communism or anticommunism. Their ideological orientation was largely amorphous. However, the collective war experience generated strong anticommunism feelings which led to a process of ideological 'purification.' The following sentences are quotations from a diary that clearly shows this ideological shift from an amorphous ideological spectrum to a polarized one:

*August 19, 1950 [under the North occupation of South Korea]

Time goes really fast, for I feel that all things happened yesterday; inmingun [the North Korean People's Army] occupied Seoul at a stroke, communists who had been hiding underground reemerged and became heroes, and every Tom, Dick, and Harry pretended to be leftists who had waged a terrific struggle (against the Rhee regime). However, that golden time seems to be gone, because most people have turned their faces away from communism although no one expresses his mind in public.

*October 22, 1950 [after the retreat of the North Korean forces from Seoul]

Because I heard Dr. Cho was back, I stopped by his house ... Although (I know that) he stood originally for the right wing (before the Korean War), he seemed to become more extreme after he took refuge. He said, "For the time being, we need to put aside a sort of democracy. And (first of all) we've got to eliminate communists thoroughly and expunge them completely from our society." ${ }^{24)}$

As one can see, the Korean War created a schizophrenic situation where Koreans were forced to choose their ideological orientation between two extreme poles, communist or anticommunism. Certainly, Koreans experienced such severe conflicts between the left and right as early as the immediate post-liberation period, and these ideological cleavages were intensified with the Cold War in the late 1940s. However, it was the Korean War that led to the predominance of anticommunism in South Korean society.

24) This diary was written from 1945 to 1951 by Sungchil Kim, a professor of Korean history at Seoul National U niversity. Sung-Chil Kim, Ryuksa-apesu [In Front of the $\mathrm{H}$ istory, Subtitled 'A Diary of a National H istorian'] (Paju, ROK: Changjakwa-bypuyungsa, 1993), p. 170 and p. 257. 
Since then, suggesting anticommunism as a bulwark for 'national' security and public freedom, the authoritarian regimes espoused anticommunism as an official ideology.

In contrast with anticommunism, developmentalism was not initiated by the authoritarian regime alone. Actually, it emerged from the post-revolutionary turmoil of the 1960s. Although the April revolution of 1960 opened the way for democracy by toppling the Rhee regime, the post-revolutionary situation evoked strong antidemocratic sentiments among intellectuals. ${ }^{25)}$ Dissatisfied with the severe poverty of the 1950s and early 1960s, moderate technocrats and intellectuals, especially those who were influenced by Rustow's transitology, turned their attention from democracy to economic growth. Needless to speak of the weak civil society at the time, such social circumstances enabled Park Chung-hee's military junta to seize power. Shortly after the military coup of May 1961, the state, claiming that the restoration of national pride had to be accomplished by economic growth, gained the support of the moderates who sought economic growth, and consolidated its power bloc by incorporating them. The authoritarian rule of the military regime controlled a weak civil society both by external measures (i.e., rewards and punishments given by the coercive state apparatus) and by internal ones (i.e., stimulating the aspirations for economic growth in the minds of Korean peoples by means of ideological apparatuses). Since then, whenever the regime faced a political challenge, the seduction of developmentalism was used to gain popular support for the suppression of political dissent. The central content of the nationalist persuasion of the regime at the time was that 'economic growth' should come first and 'political democracy' second.

\section{Two Traits of Democratic Nationalism}

The proponents of democratic nationalism shared two basic traits that set

25) Sasangkae [The W orld of Thoughts], a famous monthly journal which contributed to cementing the solidarity of antigovernment dissidents during the Rhee regime, became filled with articles about sociopolitical turbulence during the post-revolutionary period: July 1960, "The Industrialization of Asia"; January 1961, "T he Lessons from the Reconstruction of the West Germany Economy"; April 1961, "Problems of U niversity Students"; July 1961, "The Expectation for Reform." 
them apart from the advocates of statist nationalism: national reunification and popular sovereignty. Both ideas were rejected by the authoritarian regimes. The former was blocked by the anticommunist policy of the ruling elites, while the latter was rejected in the name of government intervention for economic growth. Nevertheless, democratic nationalists clearly wanted from the outset to make the point that they should not be denied or delayed. Jun-Ha Chang played a crucial role in conceptualizing national reunification within the framework of democratic nationalism. As Chang put it:

Are all forms of reunification good? Yes, they are. There is no supreme ultimatum except for reunification. If reunification means that split nations become one, and if it means the advance of national history, all that is valuable should be accomplished within reunification. Communism, democracy, equality, liberty, and prosperity - all they cannot be substantial if they conflict with reunification. When all truths, all ethics, all virtues run contrary to reunification, they are not truths but false excuses. ${ }^{26}$

This passage aims not simply to inspire an emotional desire for reunification but to attack anticommunism. When the authoritarian regime used anticommunism as an official ideology, Chang attempted to dilute its ideological power by twisting it to serve reunification. Such efforts to overcome anticommunism were continued by other dissident leaders. For instance, Seok-Hun Ham, another contemporaneous dissident leader, openly urged the Park regime to abandon anticommunism, reifying reunification as the national destiny.

Nation is a living thing. It is a living organism. And it is one of one. Even if it exists in several forms, it is one ... Please do not manipulate the term of nation.. It is akin to the way that the act of naming God is the act of handling Him ... Politics always does things like that. ${ }^{27}$

26) Jun-H a Chang, "M injokjuija-ui gil" [T he N ationalist's W ay], Ssial-ui sori [The Speeches of the People] (September 1972), in Chang-jun-ha-sunsang chumo-munjip [T he Collection for the M emory of J un-H a C hang] (Seoul: Bakbumsasangyunkyhoe, 1978), p. 17.

27) Seok-H eon H am, "M injoktonghap-ui gil" [The W ay to N ational Reunification], Ssial-ui sori (O ctober 1972), in The Collections of $\mathrm{H}$ am Seok-H un 12 (Seoul: $\mathrm{H}$ angilsa, 1984), pp. 30-31. 
Anticommunism is here elided rather easily into an account of the need for reunification, and the threat of the North seems to matter hardly at all. This is an instance of the idealist's hope for the abstract brought under the hegemony of apparently insuperable anticommunism. The appeal to reunification became an indispensable strategy by democratic nationalists to persuade Koreans to resist against the authoritarian regime and its anticommunist policy. For democratic nationalists, the struggle for national liberation could never be complete without national reunification.

The articulation of popular sovereignty with democratic nationalism was realized when dissidents groups started to argue that the appropriate agent for reunification was not the authoritarian regime but the minjung (the people). ${ }^{28)}$ This articulation echoed the indignation of democratic nationalists over the establishment of the Yushin system. Shocked by the narrow margin of his victory at the presidential election in 1971, in December 1972 President Park established a more repressive political system by creating a new constitution (called Yushin, or "revitalization"), which, he hoped, would prolong his authoritarian rule for his lifetime. The Yushin system, which was maintained by coercion, gave rise to a new ideological cleavage between 'dictatorship versus democracy' in Korean society. In other words, the more emergency measures over dissidents under the pretense of national security were wielded, the greater the Korean population became dissatisfied with the authoritarian rule. At this juncture, the rhetoric of democratic nationalism switched from reunification to popular sovereignty. Keon-Ho Song was a major activist against the Yushin system. His evocation of nationalism can show us this critical switch.

The country that has independent economic condition is politically independent. If politics is independent, national economy can be developed independently and national spirit can be independent. ${ }^{29)}$

28) In Korean, 'minjung' is a very ambiguous term. On the one hand, 'minjung' could mean the ordinary people who opposed to the state. This concept of 'minjung' contributed to the solidarity of dissident groups. On the other hand, 'minjung' could mean the lower strata which had potentially the capability of carrying out a social revolution. This latter concept became widespread when social movement sectors became radicalized in the 1980s.

29) Keon-H o Song, H ankook minjokjuui-ui tamgu [T he Study of K orean N ationalism] (Seoul: $\mathrm{H}$ angiil sa, 1977), p. 336. 
First, appropriating 'dependency theory' which was widely popular among dissidents at the time, Song denounced the Park regime as a government that had given up Korea's national sovereignty to other countries in order to preserve its authoritarian domination. For him, dependency theory was the ideal vehicle to provoke popular resentment against the authoritarian rule whose justification was always based on national security. Second, associating political accounts of popular sovereignty with explanations in terms of national independence, he emphasized that it was necessary for Koreans to replace the Park regime with a democratic government which could stimulate the independent development of the national economy. All accounts of popular sovereignty that proceed in an exclusively nationalist rhetoric are apt to underscore the need for democratization. In the 1970s, such nationalistic accounts of popular sovereignty were generally shared with other dissident groups, and eventually paved the way for the evolution of democratic nationalism from reunification to popular sovereignty.

\section{Weak Civil Society with Democratic Nationalism}

An important aspect of democratic nationalism in South Korea has been left unaddressed. This is its statist aspiration, which is crucial to understanding the reconciliation of democratic nationalism with statist nationalism after the democratization of South Korea in 1987. In this perspective, it is not so surprising that all politicians in South Korea identify themselves with nationalists, and no distinctive difference can be found in their statements on issues provoking nationalist sentiment, such as on territorial disputes and economic growth. As far as national issues are concerned, the sole serious cleavage within South Korean society is the discourse about North Korea, which swings sharply between national reunification and national security. With the exception of this issue, we can hardly see any recognizable difference among Koreans in the context of nationalism, which cannot be described any more with the binary model of statist and democratic nationalism. Investigating in what ways democratic nationalism was constrained by statist nationalism and how the former's assertion of popular sovereignty became focused on ethno-cultural factors rather than civic freedom or sociopolitical equality, in this section I demonstrate that the 
evolution of democratic nationalism in South Korea has not been revolving around the political ideal of democracy per se but around the statist aspiration of ethnic homogeneity.

\section{Democratic Nationalism during the Democratization of 1987}

Central to democratic nationalist discourse during the democratization of 1987 was the demand for direct presidential election. This relatively moderate demand for democratic reform was not originally set by the student movement whose vitality and strength in mobilizing participants in every protest during the democratization were beyond question. ${ }^{30}$ Although there was an umbrella coalition of moderate dissidents (Kookminyeonhap, the National Coalition for Democratic Constitution, hereafter NCDC) that appeared to coordinate all of the protests at that time, it was the student movement which provided particular content to democratic nationalism through evocative discourses on democratization. At this juncture, attention must be paid to the two separate but related events all of which gave rise to the de-radicalization of the student movement before the June Uprising of 1987: the 1980 Gwangju massacre and the 1987 Incheon rally. Before the June Uprising of 1987, the student movement was too radical to join in the protests organized through the nominal leadership of the NCDC. In other words, if the de-radicalization of the student movement had not occurred, the June Uprising would not have happened. It could have been the other way around. Had there not been a coalition of student activists led by the nationalist groups (the NLPDR, National Liberation and Popular Democracy Revolution) which led the de-radicalization of the student movement, the wider section of Korean society would have never joined the student demonstrations. In addition to the harsh repression of the Chun Doo-hwan regime (1980-1988), these two events posed an impetus for erasure of differences among dissidents and finally shaped the de-radicalization of the student movement at that time.

The 1980 Gwangju massacre helped to promote national consciousness in the contemporary discourse about democratization, awakening to the need for

30) Jang-Jip Choi, D emocracy after Democratization: The Korean Experience (Stanford, CA: Asia-Pacific Research Center at Stanford U niversity, 2012), pp. 83-85. 
articulating national liberation with the demand for democratization. The rupture driven by this event was the rise of anti-Americanism in the student movement which was evoked by the suspicion that the United States supported Chun Doo-hwan's military coup. Actually, the ambiguous diplomatic attitude of the United States did facilitate the rise of antiAmericanism in the student movement, not only because the army of South Korea could not move without the consent of the US-South Korean Combined Forces Command, but also because the United States openly approved of the Chun regime on many occasions. ${ }^{31)}$ Truly, this event did not generate a cross-societal anti-Americanism in the Korean society. ${ }^{32)}$ Still, it was sufficient for student activists to postulate a categorical framework with which the student movement could mount a successful claim to national sovereignty. Just as the appeal to economic growth created an abstract category in which only the authoritarian control of the strong state could be effective, so the claim to national liberation created an extended space with which the student movement could embrace the wider population of Koreans in its struggles. The student movement in this period appeared to be very radical at first glance, since it was overwhelmed by the 'social formation' debate that led student activists to inner competition for hegemony with their militancy. However, as we can see from the CNP debate, ${ }^{33)}$ claims for national

31) For instance, President Jimmy Carter said in an interview with the Boston Globe that "the Koreans are not ready for [a full-fledged democracy], according to their own judgment, and I don't know how to explain it any better" (N ew York Times, 9 August 1980).

32) Sung Chul Yang, The N orth and South Korean Political Systems (Seoul: Seoul Press \& W estview Press, 1994), pp. 452-453.

33) The CNP debate shows the ideological articulation of national liberation with democratization after the $1980 \mathrm{G}$ wangju massacre. The CDR (Civil D emocratic Revolution) group insisted to embrace the petty bourgeois and the national bourgeois as the alliance of revolution, defining the Korean society as a dependent peripheral capitalist society. The PDR (People's D emocratic Revolution) group insisted to exclude the petty bourgeois and the national bourgeois from the alliance of revolutionary coalition, defining the K orean society as a state monopolistic capitalism which had its own internal capitalist power. The NDR (N ational D emocratic Revolution) group argued a "two-stage revolution" which included the middle class and bourgeois at the first stage but excluded at the second stage, defining the Korean society as neocolonial monopolistic capitalism. See H yaeweol Choi, "The Societal Impact of Student Politics in Contemporary South Korea," H igher Education 22-2 (1991), pp. 175-188; Gi-W ook Shin et al., South Korea's D emocracy M ovement (1970-1993): Stanford Korea D emocracy Project Report (Stanford, CA: Korea D emocracy Foundation \& Shorenstein Asia Pacific Research Center, 2007), pp. 56-59. 
liberation could gain legitimacy primarily as claims to create an autonomous nation-state.

The Incheon rally of 3 May 1986 was another critical event that created an incentive for the de-radicalization of the student movement. This rally signified the triumphant moment of radical groups over nationalist groups in the social movement of South Korea, since it showed the increasing power of the labor movement after its resurface through the relaxation policy in 1984. Over twenty different radical organizations participated in the rally, and the participants of the rally outnumbered and overpowered the riot police. However, this event provided a political opportunity for the Chun regime to cope with its legitimacy crisis created by the outcome of the general election in 1985 and the democratization of the Philippines in $1986 .{ }^{34)}$ As soon as this rally was pictured as 'pro-communist' by mass media, the authoritarian regime regained the middle strata which were vacillating between 'national security' and 'public freedom.' By influencing the middle strata with anticommunism and developmentalism, the state effectively repressed antigovernment social actions and kept the initiative of political negotiation for constitutional reform. Conversely, stirred by unexpected popular opposition to the Incheon rally, nationalist groups in the student movement launched an umbrella coalition (National Liberation and Popular Democracy Revolution, NLPDR) which aimed at cementing the solidarity of student activists through the issue of national liberation. ${ }^{35}$ After seizing the hegemony of the student movement in the spring of 1987, this nationalist group decided

34) In the general election in February 1985, the New Korean Democratic Party (NKDP) which was organized in January 1985 became the largest opposition party by winning sixty-seven seats in the parliament. Although the N KD P was not able to carry out the role of opposition in the parliament, its success within such a short time made the Chun regime come to negotiations for constitutional reform including direct presidential election.

35) $O$ ne of the leaflets (Jikumsiki uriu junsuljuk immue daehayoe [O $\mathrm{n} O \mathrm{O}$ r T actical $\mathrm{M}$ ission at this M oment], 30 May 1986) distributed by the nationalist group (jamintoo) at the time clearly shows that the deradicalization of the student movement was an outcome of the interaction between ideological constraints and human practices. Emphasizing the middle strata corresponding to claims for anticommunism and economic growth, this group insisted that revolutionary vanguardism had to be replaced with a moderate united front in which the wider population of Korean peoples could be embraced. At this juncture, the nationalist groups converged into the N LPD R, replacing the two-stage revolution strategy (N ational $\mathrm{D}$ emocratic Revolution) with one stage revolution ( $N$ ational Liberation). 
to collaborate with the NCDC at the June Uprising 1987. Notably, the June Uprising could not have happened if the NLPDR had not moderated the student movement and its intransigent radical slogans. ${ }^{36)}$ But it is equally certain that the triumph of nationalist groups over radical groups in the student movement of the 1980s was the outcome of complex interactions between ideological constraints and human practices.

The hegemonic nationalist group in the student movement inherited essential elements from the democratic nationalism in the 1970s, and its slogans and practices were still constrained by the ideological power of the statist nationalism. More specifically, it reinforced ethnocentrism in democratic nationalism within which the issue of popular sovereignty was 'subordinated to' or 'merged into' that of national reunification. ${ }^{37)}$ First, 'national liberation' became a pivotal agenda in democratic nationalism, whereby the issue of ethnic homogeneity even more deeply embedded itself in the discourse of democratization. Particularly when nationalist dissidents deliberately deployed national reunification against anticommunism, the issue of ethnic unity overtly stood out as the central element of Korean nationalism. Second, the statist aspiration of democratic nationalism was accentuated most strikingly at the wake of democratization and its triumphant moment. The statist propensity of democratic nationalism entered social movements by the extent to which nationalism appeared in the guise of making democratization possible. Nak-chung Paik, a well-known cultural and political critic, shows both trends clearly in his advocacy of the reunification movement.

Reflecting on the fact that in a sense we deserved what we got in the IMF [International Monetary Fund] bailout, not only because we had neglected to secure advanced institutions but also we lived distractedly without accomplishing real nation-building, we must apply the criteria of our immediate task of overcoming the division system in evaluating and actively coping with the demands for 'reform' by the IMF and other leading forces of world capitalism. ${ }^{38}$

36) In-Young Lee, the leader of the N LPDR at the time, confirmed this fact during the interview with me on 15 D ecember 1995.

37) Gi-W ook Shin, Ethnic N ationalism in Korea: Genealogy, Politics, and Legacy (Stanford, CA: Stanford U niversity Press, 2006), pp. 185-203. 
Lamenting over the public negligence of the need for reunification since the financial crisis of South Korea in 1997, Paik raises the possibility that the sociopolitical problems exposed by the IMF bailout arise less from the stagnation of democratization itself than the sustenance of the 'division system.' ${ }^{39)}$ At this juncture, his notion of the division system appears to have rendered the sociopolitical problems of South Korea in the context of democratic nationalism as opposed to anticommunism, and thereby he invites future democratic dissidents to recast 'reunification' as a more imperative doctrine than 'democratization', urging that 'nation-building' has not been accomplished yet. He denies that his "theory of the division system" is identical with the conception of 'national liberation' that emerged during the democratization of South Korea in 1987. ${ }^{40)}$ However, the very content of his nationalistic rhetoric is not so much different from the idea of national liberation. The desire for national liberation becomes particularly clear when he takes the IMF bailout as an example of the "serious infringements on sovereignty" ${ }^{41)}$ and when he equivocates "the Korean ethnic community" as a practical or ultimate source to overcome the division system. ${ }^{42)}$

All in all, when democratic nationalism stubbornly continued to consider nationalism as a crucial instrument of democratization, the envisioning of national reunification through nationalism rather than the indispensable values of democracy such as liberty and equality is in many cases imposed by democratic nationalists on the Korean people. The statist aspiration, which has been fused deeply with the conflation of democratic nationalism into ethnocentric nationalism in the Korean society, still plays a decisive role in appreciating democratic nationalism and its normative presuppositions. The

38) N ak-Chung Paik, The Division System in Crisis: Essays on Contemporary Korea, trans. by M yung-hwan Kim, June-Kyu Sol, Seung-chel Song, and Young-joo Ryu, with collaboration of the author (Berkeley, CA: U niversity of California Press, 2011), p. 40.

39) By and large, Paik attributes the failure of the post-1987 democratic reforms to what he defines as the "division system" in which the N orth-South confrontation accelerates division, rather than reunification in the Korean peninsula. Accordingly, the division system has various aspects relating not only to the respective political systems of $\mathrm{N}$ orth and South Korea and their participation in the capitalist world-economy but to the sociopolitical structures of the Cold War in the two Koreas and their domestication in the daily practices of N orth and South Koreans. See I bid., pp. 3-35.

40) I bid., pp. 38-39.

41) I bid., pp. 39-40.

42) I bid., pp. 96-99. 
statist aspiration, by giving priority to political unity over democratic contestability, formulates a predicament in which democratic nationalism can hardly harness the realization of a free and equal democracy to its normative presuppositions for civic allegiance. Under the shadow of the statist aspiration, democratic nationalism can be misconstrued to defuse diversity which is by definition the best way to protect citizens from the undemocratic tendencies of statist nationalism. As a result, democratic nationalism contributed to the trend of social movement after the democratization of 1987 that the primacy of democratization was granted to the pursuit of the state power over the reinforcement of civil society.

\section{Idiosyncrasy of Weak Civil Society in South Korea}

The indigenous strength of the statist aspiration in South Korean society is particularly problematic when we consider democracy in terms of civil society and its reinforcement in public life. Since the democratization of 1987, Koreans have observed that nationalism cannot develop the values of democracy save popular sovereignty. As for popular sovereignty, we observe that its articulation with nationalism is unable to implement sociopolitical reforms and cultural changes for strengthening civil society. Certainly, Koreans enjoy democracy in a Schumpeterian sense that the locus of power is decided by competitive struggle for people's vote. However, Koreans are experiencing a paradox: while the Korean political system is moving fast toward constitutional democracy in which elections can make the government more accountable for its conduct, politics is frequently slipping back into some of the socio-ideological schemas previously structured by statist nationalism. In this respect, although Koreans can congratulate themselves for the fact that the social movement sector has played a crucial role in the democratization process, they should equally deplore that citizens in general remain a passive and an incoherent mass responding only intermittently to the dramatic issue raised by politicians and militant political activists.

Various social indices show that Koreans must ponder the idiosyncrasy of weak civil society. First, they need to consider the recent neoliberal changes that have affected not only their daily lives but also their societal imaginations. Koreans become 'enterprising selves,' which designate the modes through which a society allocates civic responsibility to the matters of individual's 
ability to self-management. ${ }^{43)}$ As the 2006 statistical record conducted by the National Statistical Office shows, $76.9 \%$ of the citizens who are over 15 years old chose socioeconomic inequality as one of the most important problems of contemporary Korean society. Furthermore, $10.3 \%$ of these citizens replied that they contemplated to commit suicide because of their economic hardship. Similar results can be found in public surveys. For instance, according to Gallup's 2007 investigation, the number of those who considered wealth as the most critical for determining their lives increased from 35.8\% in 1997 to $60.5 \%$. Despite such records, Korean society does not appear to be ready to talk about sharing these sociopolitical burdens together with one another. The proportion of public antipoverty effort is still very low ${ }^{44)}$ and private transfers, rather than public transfer, are the most crucial in alleviating poverty and inequality ${ }^{45)}$ In brief, different from what civic nationalists expect from nationalism, the strong national commonality among Koreans failed to generate an environment with which the Korean society protects its citizens from neoliberal individualization transfiguring collective responsibility into individual enterprises.

Second, we need to pay attention to growing social distrust in Korean society, not only between the state and civil society but also between citizens. Koreans are not so strongly satisfied with political and social institutions, though Korean society has undergone an improvement in the process of economic growth and political democratization. As we can see from Korea's position in the Corruption Perception Index (CPI) - which has been ranked in the lowest stratum for the last ten years - in Korean society, the low rate of public reliance on political organizations and social institutions (consistently below 6\%) is problematic. Distrust among citizens is a problem which has become serious since the democratization of 1987. As empirical researches show, voluntary participation in private and public associations in Korean society is only one-fifth of that in other OECD countries, and voluntary

43) Thomas Lemke, "The Birth of Bio-Politics: M ichel Foucault's Lecture at the College de France on N eo-Liberal Govermentality," Economy and Society 30-2 (2001), pp. 190-207.

44) Jae-Sung Choi and Jeong-K yun Choi, "The Effectiveness of Poverty Reduction and the Target Efficiency of Social Security Transfers in South Korea, 1999-2003," International Journal of Social Welfare 16-2 (2007), pp. 183-189.

45) H uck-J u K won, "Income T ransfers to the Elderly in Korea and Taiwan," Journal of Social Policy 30-1 (2001), pp. 81-93. 
associations with authoritarian cultures are not open to outsiders and different voices ${ }^{46)}$ Under such circumstances, we can hardly expect that a democratic deliberation between different social strata as well as between peoples with different opinions can be held effectively.

Despite these social indices, current narratives of democratic nationalism in the Korean society explicitly or implicitly encourage a public conviction that one's own country should be considered superior to all others. Certainly, a healthy democracy requires civic pride with which citizens can be inspired to feel gratitude toward their political community, fidelity toward their traditions, and a willingness to ensure that their political community remains free and prosperous. Still, the advocacy of civic solidarity does not need to entail a public belief that national unity should be precedent over any other democratic values or one's own country should be superior to others. Otherwise, democratic nationalism cannot nurture social formations for a strong civil society with which democratic deliberation between citizens in conflict can improve the quality of democracy. Nevertheless, the pervasive image of democratic nationalism in Korean society is exceedingly preoccupied with ethnocentric and statist aspiration for national reunification and economic growth. In this circumstance, it is more than somewhat inevitable that nationalist discourses are insulated from debates over the values of democracy. In other words, the current articulation of democratic nationalism with neoliberal individuals in the Korean society cannot nurture a civic solidarity which eventually contributes to the consolidation of democracy through democratic deliberation.

\section{Intermediated Ideal for Civic Solidarity}

At this juncture, Viroli's theory of 'republican patriotism' is attractive in the sense that it can provide us with a moderate version of collective commonality which is not an ideological interpellation featured by nationalism. In his view, democratic commonality should not be confused with any type of nationalism for the following two reasons: First, in republican patriotism, love of one's

46) Jaeyeol Yee and D ukjin Chang, "T ransparency, a K ey Factor to Improve Social Cohesion: A Review of the Korean Experience in the Context of Social Q uality Research," Development and Society 38-2 (2009), pp. 259-275. 
country is an 'artificial' affection, rather than a 'natural' feeling. ${ }^{47)}$ Second, republican patriotism - unlike nationalism that recognizes no other duty than advancing a nation's interest -emphasizes the importance of republican values which could expand to form the basis of a love for humanity ${ }^{48)}$ These lines of argument point out that democratic commonality should oppose ethnic nationalism which emphasizes the primacy of cultural homogeneity over cultural diversity. Even if democratic commonality is entangled with feelings of solidarity rooted in pre-political bonds demanding special affection to a particular country, it should dissociate itself from any inclination for the unity of ethnicity and culture. In this context, Viroli holds the view that democratic commonality should be based on the very condition that no one is subordinated to the arbitrary will of others - that is, in a free republic which can ensure liberty as non-domination.

Certainly, Viroli's theory of republican patriotism needs to be supplemented in various aspects. Most importantly, this theory should clarify a regulative ideal beyond pre-political factors which is comprehensible for all who lack a republican tradition, or who have lost republican tradition, or who endeavor to realize liberty as non-domination. Assuming that republican patriotism should be based on liberty as non-domination, Viroli does not hesitate to urge that "if our fatherland is unfree we have to work to make it free instead of leaving to look for liberty elsewhere." ${ }^{\left.{ }^{49}\right)}$ In addition to civic allegiance, Viroli counsels patriots to appeal to emotions rooted in pre-political elementsnamely, language, culture, and history - for encouraging compatriots to dedicate themselves to the common good of the people. ${ }^{50)}$ In sum, while he puts forth the shared experience of common liberty as the essential condition for engendering republican patriotism, he draws love of common liberty from pre-political and non-republican bonds which are not necessarily entangled with liberty as non-domination and its enjoyment. Nevertheless, it is important for us to see that democratic commonality can be shaped or needs to be constructed by the actual experience of liberty as non-domination.

I believe that democratic commonality based on reciprocal non-domination

47) M aurizio Viroli, Republicanism (N ew York: $\mathrm{H}$ ill and W ang, 2002), pp. 13-15.

48) I bid., p. 85.

49) M aurizio Viroli, For Love of Country: An Essay on Patriotism and N ationalism (N ew York: O xford U niversity Press, 1995), p. 9.

50) Ibid., p. 10. 
as a regulative principle can provide a civic ground for democratic deliberation by taming the ethnocentric factors of democratic nationalism. This notion of reciprocal non-domination draws at least two imperative demarcation lines between democratic commonality and those conceptions whose basis is either a self-governing ethical and cultural community or a myth of ethnic homogeneity. First, it distinguishes democratic commonality from ethnocentric nationalism which does not allow exogenously given intermediate values to moderate loyalty to a particular community. However, to sustain the democratic value of liberty as non-domination, I urge that an adherent of democratic commonality should be aware of his/her moral obligations toward the values of democracy, such as liberty and equality. Second, this notion dissociates democratic commonality from any form of procedural democracies whose normative claims are attached to a universal or neutral point of view. Unless the enjoyment of civil and political rights rooted in a particular political and cultural community is constituted as a significant element of civic solidarity, democratic commonality will be vulnerable to a chauvinistic and bellicose nationalism.

\section{Conclusion}

This article explores the limits of democratic nationalism whose political claims to civic unity cannot dissolve the internal discrepancy of nationalistic commonality in South Korean society, which oscillates between the strong nationalistic sentiment and the weak local affinity, and partly between the collective political agency reacting only to dramatic issues and the atomized neoliberal individual without civic responsibility. I have shown that this peculiarity of democratic nationalism in Korean society originates largely from its degeneration into ethnocentric nationalism, which was accompanied by the disappearance of democratic ideals from nationalist discourses after the democratization of 1987. Since then, the exclusive focus on ethnocentric culture in Korean society has neglected social formations for strong civil society. In this context, I have made the following two arguments: First, I claim that democratic nationalism should be more closely connected to the values of democracy. The values underlying the justification of statist and ethnocentric nationalism in Korean society exaggerate the urgency of social 
bond at the expense of civic-democratic legitimacy. The best defense for thinking of democratic commonality as a civic and democratic sentiment is the values of democracy themselves. Second, I maintain that liberty as nondomination can provide us with an intermediate ideal conducive to regulate differences in opinion and power through democratic deliberation. I believe that reciprocal non-domination as a regulative ideal would favorably modify the distorted relationship between democratic passion and ethnic nationalism in the Korean society.

Today Koreans are experiencing a new sociopolitical phenomena shaped partly by the neoliberal change and partly by populist aspiration. Although Koreans accept the neoliberal principles in their daily lives, they still demand a collective identity which can resolve individual anxieties originating in social disorganization. Hence, there is a reasonable concern that neoliberal propensities connected with nationalism might degenerate into a quasitotalitarian advocacy of political integration in a sociopolitical crisis. This is not only because citizens have been responding only to the dramatic issues driven by militant activists but also because their democratic potentiality has not been reformulated into an institutional reform by democratic commonality. In this context, I believe that we need to pursue an alternative democratic commonality in the fashion that the sociopolitical problems which had been ascribed to individuals should be regarded as the publicly shared responsibility; the state which has been neutral in the market economy must act on providing socially marginalized groups with conditions to be free from the arbitrary will of other peoples; and civic responsibility that has become obsolete could be rehabilitated without harming social plurality and individual freedom.

\section{REFERENCES}

Bohman, James. Public Deliberation: Pluralism, Complexity, and Democracy. Cambridge, Massachusetts: MIT Press, 1996.

Calhoun, Craig. Nations Matter: Culture, History, and the Cosmopolitan Dream. New York: Routledge, 2007.

Chang, Jun-Ha. "Minjokjuija-ui gil" [The Nationalist's Way]. Ssial-ui sori [The Speeches of the People]. In Chang-jun-ha-sunsang chumo- 
munjip [The Collection for the Memory of Jun-Ha Chang]. Seoul: Bakbumsasangyunkyhoe, September 1978 [1972].

Choi, Hyaeweol. "The Societal Impact of Student Politics in Contemporary South Korea." Higher Education 22-2. August 1991, pp. 175-188.

Choi, Jae-Sung and Jeong-Kyun Choi. "The Effectiveness of Poverty Reduction and the Target Efficiency of Social Security Transfers in South Korea, 1999-2003." International Journal of Social Welfare 162. April 2007, pp. 183-189.

Choi, Jang-Jip. Democracy after Democratization: The Korean Experience.

Stanford, California: Asia-Pacific Research Center at Stanford University, 2012.

Dryzek, John. Discursive Democracy: Politics, Policy, and Political Science.

Cambridge, Massachusetts: Cambridge University, 1990.

Dzur, Albert W. "Nationalism, Liberalism, and Democracy." Political Research Quarterly 55-1. March 2002, pp. 191-211.

Gans, Chaim. The Limits of Nationalism. New York: Cambridge University Press, 2003.

Greenfeld, Liah. Nationalism: Five Roads to Modernity. Cambridge, Massachusetts: Harvard University Press, 1993.

Habermas, Jürgen. The Inclusion of the Other: Studies in Political Theory. Translated by Ciaran Cronin. Cambridge, Massachusetts: MIT Press, 1996.

Harris, Nigel. National Liberation. Reno, Nevada: University of Nevada Press, 1990.

Herr, Ranjoo S. "In Defense of Nonliberal Nationalism." Political Theory 343. June 2006, pp. 304-327.

Kim, Sung-Chil. Ryuksa-apesu [In Front of the History, Subtitled 'A Diary of a National Historian']. Paju, ROK: Changjakwa-bypuyungsa, 1993.

Kohn, Hans. The Idea of Nationalism: A Study in Its Origins and Background. New Brunswick, New Jersey: Transaction Publishers, 2005 [1944].

Kwon, Huck-Ju. "Income Transfers to the Elderly in Korea and Taiwan." Journal of Social Policy 30-1. January 2001, pp. 81-93.

Kymlicka, Will. Multicultural Citizenship: A Liberal Theory of Minority Rights. New York: Oxford University Press, 1996.

Lemke, Thomas. "The Birth of Bio-Politics: Michel Foucault's Lecture at the College de France on Neo-Liberal Governmentality." Economy and Society 30-2. March 2001, pp. 190-207.

Manent, Pierre. Democracy without Nations? The Fate of Self-Government in 
Europe. Translated by Paul Seaton. Wilmington, Delaware: Intercollegiate Studies Institute, 2007.

Mansfield, Edward and Jack Snyder. "Democratization and War." Foreign Affairs 74-3. May-June 1995, pp. 79-97.

Nodia, Ghia. "Nationalism and Democracy." Journal of Democracy 3-4. October 1992, pp. 3-22.

Paik, Nak-Chung. The Division System in Crisis: Essays on Contemporary Korea. Translated by Myung-hwan Kim, June-Kyu Sol, Seung-chel Song, and Young-joo Ryu, with collaboration of the author. Berkeley, California: University of California Press, 2011.

Pamir, Peri. "Nationalism, Ethnicity and Democracy: Contemporary Manifestations." International Journal of Peace Studies 2-2. July 1997.

Available at <http://www.gmu.edu/programs/icar/ijps/vol2_2/ pamir.htm> (Accessed on 3 March 2013).

Rustow, Dankwart. "Transitions to Democracy: Toward a Dynamic Model."

In Lisa Anderson. ed. Transitions to Democracy. New York: Columbia University Press, 1999 [1969], pp. 18-37.

Rutland, Peter. "Democracy and Nationalism in Armenia." Europe-Asia Studies 46-5. June 1994, pp. 839-861.

Shin, Gi-Wook. Ethnic Nationalism in Korea: Genealogy, Politics, and Legacy. Stanford, California: Stanford University Press, 2006.

Shin, Gi-Wook, Paul Chang, Jung-eun Lee, and Sookyung Kim. South Korea's Democracy Movement (1970-1993): Stanford Korea Democracy Project Report. Stanford, California: Korea Democracy Foundation \& Shorenstein Asia Pacific Research Center, Stanford University, 2007.

Snyder, Jack. From Voting to Violence: Democratization and Nationalist Conflict. New York: W. W. Norton, 2000.

Social Science Korea-Civic Solidarity Research Group. Social Survey on Civic Solidarity in South Korea. Seoul: Korea University, 2012.

Song, Keon-Ho. Hankook minjokjuui-ui tamgu [The Study of Korean Nationalism]. Seoul: Hangilsa, 1977.

Szabo, Mate. "Nation-State, Nationalism and the Prospects for Democratization in East Central Europe." Communist and Post-Communist Studies 274. December 1994, pp. 337-399.

Tamir, Yael. Liberal Nationalism. Princeton, New Jersey: Princeton University Press, 1995.

Viroli, Maurizio. For Love of Country: An Essay on Patriotism and Nationalism. 
New York: Oxford University Press, 1995.

Republicanism. New York: Hill and Wang, 2002.

Yack, Bernard. "Popular Sovereignty and Nationalism." Political Theory 294. August 2001, pp. 517-536.

Yang, Sung Chul. The North and South Korean Political Systems. Seoul: Seoul Press \& Westview Press, 1994.

Yee, Jaeyeol and Dukjin Chang. "Transparency, a Key Factor to Improve Social Cohesion: A Review of the Korean Experience in the Context of Social Quality Research." Development and Society 38-2. December 2009, pp. 259-275.

[Received March 31, 2013; Revised J une 10, 2013; Accepted J une 11, 2013] 